\title{
Foreign language skills as the ultimate 21 st century global competency: Empowerment in a globalized world
}

\author{
Stein-Smith, Kathleen $\$ \\ Fairleigh Dickinson University - Metropolitan Campus, USA (kathysteinsmith@gmail.com)
}

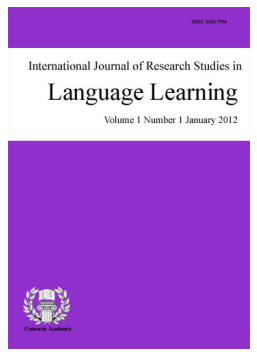

ISSN: $2243-7754$ Online ISSN: 2243-7762

OPEN ACCESS

\section{Abstract}

In a world where we are all talking, tweeting and live-streaming with each other, we must be able to understand each other - foreign languages are the ultimate social media tool! Foreign language skills are the ultimate, overarching 21 st century global competency, important in our careers and in our lives as local and global citizens. Yet, in the U.S., fewer than $20 \%$ of K-12 public school students study another language and only $8 \%$ of college and university are enrolled in a course in a language other than English. In addition, only one in four Americans is capable of holding a conversation in another language. This U.S. foreign language deficit has a negative impact on our economic and national security, and on our ability to effectively navigate the multilingual world. 2017 has been a watershed year for foreign languages in the U.S. The 2017 reports, America's Languages: Investing in Language Education for the 21st Century, Not Lost in Translation: The Growing Importance of Foreign Language Skills in the U.S. Job Market, and The National K-12 Foreign Language Enrollment Survey are poised to propel foreign languages into the center of the current public and academic conversation on education in the U.S. Knowledge is power, and foreign language skills and cultural knowledge empower foreign language learners and speakers to appreciate and understand other cultures and to examine global issues from multiple perspectives. They bring us personal and professional benefits and can encourage the development of a global citizenship mindset and values. The U.S. needs to address overcome the U.S. foreign language deficit through increasing awareness, motivation, access, and pre-professional curriculum, and through effective advocacy. Knowledge is power, and foreign language skills and cultural knowledge empower us personally, professionally, and as global citizens. Foreign language skills and knowledge of other cultures are an essential 21 st century social skill for individuals in their personal lives, as professionals in a globalized marketplace, and as global citizens in a globalized world. This study is intended as advocacy research, to support the work of foreign language educators and advocates in the U.S. and beyond, and draws upon the theory and practice of change management, social marketing, and the psychology of influence to effectively address the longstanding deficit in foreign language knowledge among 
Stein-Smith, K.

Anglophone Americans, and to a large extent Anglophone societies worldwide, caused in part by a belief that English is the global lingua franca and that no additional languages are needed.

Keywords: foreign language deficit; foreign language skills; multilingualism; global citizens 


\section{Foreign language skills as the ultimate 21st century global competency: Empowerment in a globalized world}

\section{Introduction}

In a world where we are all talking, tweeting and live-streaming with each other, we must be able to understand each other - foreign languages are the ultimate social media tool! Foreign language skills are the ultimate, overarching 21st century global competency, important in our careers and in our lives as local and global citizens. The 2017 reports, America's Languages: Investing in Language Education for the 21st Century, Not Lost in Translation: The Growing Importance of Foreign Language Skills in the U.S. Job Market, and The National K-12 Foreign Language Enrollment Survey are poised to propel foreign languages into the center of the current public and academic conversation on education in the U.S.

Knowledge is power, and foreign language skills and cultural knowledge empower foreign language learners and speakers to appreciate and understand other cultures and to examine global issues from multiple perspectives. They bring us personal and professional benefits and can encourage the development of a global citizenship mindset and values. Foreign language skills are a social, informational, and professional skill, but most importantly, they are a global competency fostering the development of a global mindset and global citizenship core values in a globalized world.

Marian and Shook (2012) are among those who have demonstrated that foreign language skills have cognitive benefits, including problem-solving, decision-making, a delay in the onset of dementia, and better test scores; and cultural benefits, including the ability to understand and appreciate other cultures at home, through film, literature, and media, and in direct contact either at home or during travel. In addition, professional benefits include increased earnings and employability.

Foreign language study, even without the attainment of proficiency and/or fluency as is the case for so many Americans, and mere exposure to foreign languages, can also be beneficial in terms of awareness, acceptance, and understanding of the challenges many face in learning a new language as they adapt to a new home (Kinzler, 2016; Reagan, 2004). This is especially encouraging news for language learners. While proficiency and fluency are valid goals, even basic knowledge is an advantage in understanding the world around us.

Foreign languages impact the global economy as well, with shared language facilitating trade, and foreign language skills a must for international business, whether in import/export, services, or U.S. multinationals overseas. On an individual level, increased earnings and employability are associated with foreign language skills. National and global security are also reliant on foreign language skills, with knowledge and understanding of other languages and cultures essential in fostering dialogue, in avoiding potential threats, and in effectively addressing in a multilateral manner complex global issues including the United Nations Sustainable Development Goals (SDGs) (United Nations, 2015). However, relatively few Americans speak a language other than English. Americans are among the least likely in the world to speak another language, and the U.S. foreign language deficit negatively impacts our economic and national security, as well as our career prospects and our ability to effectively navigate the globalized world and workplace, and our multilingual and multicultural society. the increasingly multilingual world. This highlights an opportunity for foreign languages to be re-considered in an increasingly global world and workplace.

According to a Gallup poll (McComb, 2005), 25\% of Americans report the ability to hold a conversation in a language other than English, and if recent immigrants and other heritage speakers are deducted, the number falls easily to $10 \%$. On the other hand, $54 \%$ of Europeans have reported the capability to hold a conversation in a second language, $25 \%$ in two additional languages, and $10 \%$ in more than two additional languages (Europeans 
Stein-Smith, K.

and Their Languages, 2012).

America's Languages: Investing in Language Education for the $21^{\text {st }}$ Century (2017) outlines the current status of languages in the U.S. and makes recommendations for educational institutions. Among its key findings listed in its Executive Summary are that foreign language skills are of critical importance in the 21st century, that the U.S. needs to increase its foreign language capacity, and that the U.S. lags behind in the percentage of the population with foreign language skills as compared to many nations. Not Lost in Translation: The Growing Importance of Foreign Language Skills in the U.S. Job Market (2017) highlights the dramatic increase in demand for foreign language skills in the U.S. workplace in a wide variety of positions.

\section{Foreign Language Skills as the Ultimate 21st Century Competency}

Impacting our personal and professional lives, fostering the development of a global citizenship mindset and values, and correlated with creativity and problem-solving, foreign language skills are actually the overarching 21 st century social, global, and informational competency. In a globalized and interconnected world and workplace, effective communication with those who speak other languages is essential. In terms of information, those with foreign language proficiency are able to access education and information from a broader range of sources, resulting in a more well-informed and balanced skills set and worldview. With fake news, junk news, and alternative facts throughout the news and social media -- and making news in and of themselves, the awareness of the international news media and press and the ability to access news and information from sources around the world, in their original language, only strengthen the case to be made for the importance of foreign language skills as the ultimate, overarching 21 st century competency. Foreign language skills are a personal skill, a professional skill, an informational skill, and linking these, a social skill and global skill. While fluency is a valid goal, even basic communicative skills will set the foreign language learner apart in a competitive workplace.

\section{Foreign Language Skills as a Personal Skill}

Foreign language skills and knowledge of other cultures provide cognitive, social, and cultural benefits. Foreign language learning has been linked to improved scores on standardized tests, and studies have shown that 3regular use of another language can stave off the onset of dementia. Social benefits include the ability to directly communicate with others at home and abroad. Cultural benefits include the ability to appreciate literature, vocal music, movies, and the popular media in the original language. In addition, use of more than one language has been linked to creativity and problem-solving. Study and travel abroad can become easier and can be more meaningful for those with foreign language skills.

\subsection{Recognizing Fake News}

Foreign language skills and knowledge of other cultures are among the best skills in recognizing fake news. Knowledge and experience of other cultures provide perspective when accessing a print, online, or media news source, making it easier to discern whether a particular news story is plausible, and if true, whether it is in alignment with core values and beliefs operating in another part of the world. In addition to the recognition and understanding of other worldviews learned through experience with other cultures, foreign language skills provide direct access to news stories produced around the world for both local and international audiences.

Access to news sources in the original language from more than one country or region always provides perspective, but is even of more critical importance where freedom of the press is an issue. The ability to think critically is already a well-known skill gap in the modern workplace, and foreign language skills provide the learner with the ability to compare and analyze multiple news sources. Such an ability provides the learner with additional levels of cultural and emotional intelligence so critical to success in the modern socio-economic landscape. 
Foreign language skills as the ultimate 21st century global competency: Empowerment in a globalized world

\section{The Global Economic Importance of Foreign Language Skills}

A shared language can make it easier to conduct business, to establish an organization in a new business environment, and to achieve success - for reasons that stem from language as a social, informational, and communicative skill in the globalized marketplace. Employers in both the U.S. and the UK seek foreign language skills in employees, with demand for foreign language skills exceeding supply (Heitner \& Miller, 2011; British Council, 2014). The OIF report, La Langue française dans le monde (2014) highlights the correlation of a shared language, in this case French, on ease of doing business, market penetration and the subsequent volume of trade.

As far as U.S. trade is concerned, while it is not surprising that Canada, for reasons of proximity and the NAFTA agreement, is the top destination for US exports, it is somewhat more surprising that the UK, a member of the EU, is the top European destination, and \#5 destination overall, for our exports (Census, 2016). Conversely, if a shared language supports international business and trade, it is important to think about our top export destinations, which include Mexico, China, Japan, and Germany, and the languages they speak and in which they conduct business. In fact, most of the major trading partners of the U.S. are countries in which English is not the official language. After all, as is often attributed to Willy Brandt, "If I'm selling to you, I speak your language. If I'm buying, dann müssen Sie Deutsch sprechen!

The importance of foreign language skills and cultural knowledge is also demonstrated by their role in global talent, in the import-export sector, and in terms of 12M U.S. jobs attributable to foreign direct investment, 6.1M of which include U.S. workers employed by foreign-owned companies operating in the U.S. (ITA, 2016). In addition, many U.S. companies generate a significant portion of their revenue abroad. In 2015, S\&P 500 companies generated over half their revenue overseas, with Asia and Europe the largest revenue sources (Goldstein, 2015).

The tourism sector, where foreign language skills and cultural knowledge play a significant role accounts for $9 \%$ of global employment, 1 out of 11 jobs worldwide, and 10\% of GDP, with 1.2B international arrivals per year (UNWTO). The ability to understand and relate to different cultures and languages is big business, impacting many sectors. Partly because of globalization, the foreign language sector itself is expanding, currently generating $\$ 40 \mathrm{~B}$ per year in revenue and predicted to rise to $\$ 45 \mathrm{~B}$ by 2020 (Gala-Global, 2017). Three of the top 5 language services firms are headquartered in the U.S. (Commonsense Advisory, 2016), and the U.S. accounts for almost 35\% of the global language services market (LingoKing, 2016).

In the U.S., jobs in translation and interpreting are predicted to rise by $29 \%$ in 2014-2024, "much faster than average" (Occupational Outlook Handbook, n.d.). Opportunities for postsecondary foreign language teachers are predicted to increase by $9 \%$ to $13 \%$, "faster than average," in 2014-2024, and opportunities for high school teachers, including foreign language teachers are predicted to increase by $8 \%$, or "average" (O*Net, n.d.).

The economic impact of language learning is also considerable, with the French government spending over $600 \mathrm{M}$ euro a year on the promotion of French. Berlitz earns $75 \%$ of its revenue teaching English(Economist, 2013). Rosetta Stone 2016 revenue was \$51.7M. Simon \$ Schuster Pimsleur revenue was estimated at \$5.8M (Owler, 2017). Global revenue for digital English learning products is predicted to reach \$3.B by 2018 (Ambient, 2013). In the UK, the English Language Teaching (ELT) sector is estimated to have generated $£ 1.2$ billion (US\$1.74 billion) for 2014, with a total economic impact of $£ 2.4$ billion (US\$3.48 billion) (ICEF, 2016).

International education and study abroad have both linguistic and economic impact. In 2015/2016, 1,043,839 international students studied in the U.S., and 313,415 U.S students studied abroad in 2013/1014, and international students contributed $\$ 35.8$ billion to the U.S. economy in 2015 (Open Doors, 2016). Foreign language learning for U.S. students planning study abroad, and English language learning for international students are significant economic factors. In addition to having global economic importance, foreign language skills are also a professional and career asset. 


\section{Foreign Language Skills as a Career or Professional Skill}

According to Not Lost in Translation: The Growing Importance of Foreign Language Skills in the U.S. Job Market (2017), foreign language skills are in demand in the U.S. workplace, both in terms of international business and of the increasingly multilingual U.S. society, with demand doubling between 2010 and 2015. Taking the importance of language in the workplace further, Neeley and Kaplan (2014) argue that all business organizations benefit from the development of a language strategy. At the same time, U.S. businesses are actively seeking employees with global talent - professionals across the disciplines who have the foreign language skills and cultural knowledge needed in both the globalized marketplace and a multilingual and multicultural US marketplace (JNCL-NCLIS, 2015). Overall, foreign language skills are among the most sought-after workplace skills (Kurtz, 2013).

Career options for Americans and other Anglophones with foreign language skills may either require foreign language skills, or benefit from them, and include opportunities in the language services industry, education, government, international business, tourism, and teaching English as a Second Language. In addition to increased career opportunities, the benefits of foreign language skills in the workplace include enhanced earning capacity (Economist, 2014). According to the National Association of Colleges and Employers, foreign language majors are the top earners among graduates with liberal arts majors (NACE, 2016). JNCL-NCLIS (2015) has reported on the importance of foreign language skills and cultural knowledge in global talent.

In addition, opportunities for foreign language teachers are likely to increase, especially after the release of the report, America's Languages (2017), the report from the Commission on Language Learning, which includes among its key recommendations increasing the number of foreign languages at all levels so that all U.S schoolchildren have the opportunity to learn another language. The decision as to which language to learn also depends on your professional plans. According to Bloomberg (2011), the top three languages for business are English, Mandarin Chinese, and French. German and French have been shown to contribute the most in lifetime earnings (Johnson, 2014). In addition, your profession and your present and potential geographic locations may point to one or more target languages. The role of foreign language skills as a professional and career skill is linked to the role of foreign language as an informational skill, which includes, but is not limited to, access to education and training both online and in traditional settings, online and broadcast media, magazines, newspapers, books, and the internet.

\section{Foreign Language Skills and Multilingualism as a 21st Century Informational Skill}

The contemporary era is often referred to as the information age, and knowledge of other languages opens the door to expanded access to information through the press, media, and social media, as well as through more traditional forms of cultural expression. Global languages like French and English provide access to information through a multiplicity of print, broadcast, and online media, and to education through online learning and study abroad. However, not all information is readily available in any one particular language.

English, Chinese, and Spanish are the most frequently used languages on the internet, but all of the six official languages of the UN are among the top 10 (Statista, 2017). English-language pages are among the most frequently visited on Wikipedia, followed by those in Japanese, Spanish, and German (Pew, 2016). The U.S., China, and Germany publish the largest number of books per year (IPA, 2014).

According to the OIF (2014), a survey across 25 cities in 12 African countries revealed that $50 \%$ of those surveyed considered French an advantage in their personal and professional lives, and in access to information and education. The power of foreign language skills, in this case providing access to the news and media, professional and educational information, the internet, as well as to entertainment through film and music, through knowledge of French, a global language, provides a gateway to information not necessary available through a local or regional language. 
Foreign language skills as the ultimate 21st century global competency: Empowerment in a globalized world

The depth of the connection between language and communication is highlighted in the oft-heard concept (McLuhan, 1967) that the medium -- in this case, the language with all its connotations and contexts -- is an integral part of any message. For that reason, the person who only hears a message in translation, albeit a correct and excellent translation, has in fact only heard part of the message or information. If one takes into account the idea that a specific means of communication may be better suited to specific types of communication, this dovetails with the impression of many bilinguals and multilinguals that one language may lend itself better to communication on a specific topic, or topics, than another (Grosjean, 2010).

The idea that knowledge is, indeed, power can certainly be applied to the relative position of those with foreign language knowledge and skills, who enjoy an advantage in all manner of social and professional exchanges. Foreign language skills mean empowerment, characterized by the ability to pick up cultural and contextual nuances that others, receiving a translation, would most like overlook or miss altogether. With international travel at the highest level in recorded history and still increasing, more and more travelers are in need of information, often only available in a local language. In 2014, there were over 1.1B international arrivals per year, and France remains the leader in international visitors with 83M in 2016 (Hosie, 2017)

In terms of student global mobility, foreign language skills and cultural knowledge are an advantage both for the international student and for local educators and service providers working with them. According to the OECD, 5M students are studying outside their home country, with China and India the leading sources of students (ICEF, 2015). According to the Open Doors report (2016), over 1M international students were studying in the U.S. in 2015, with China, India, South Korea, and Saudi Arabia the top countries of origin. Over 300,000 U.S. students were studying abroad during the same period, with the UK, Italy, Spain, France, and China the leading destinations.

In addition to international and global benefits of foreign language skills, knowledge of another language is useful in an increasingly multicultural U.S. According to the Census (2013), in the U.S., over 60 million people over the age of 5 speak a language other than English in the home, 21\% of the total U.S. population, with Spanish, Chinese, and French/French Creole the top three (Ryan, 2013). In addition, and importantly, foreign language skills facilitate access not only to education, but to news and news media in other languages, offering access to other perspectives and worldviews. This access to news media around the world is especially important at a time when fake news and junk news are a source of concern worldwide.

\section{Multilingualism as a 21st Century Social Skill}

In a world where we are all talking, tweeting and live-streaming with each other, we must be able to understand each other - foreign languages are the ultimate social media tool! Research even points to the relationship between hearing other languages around us, as in a large global city or other similarly multilingual environment, and the development of many of the advantages frequently associated with bilingualism (Kinzler, 2016). Foreign language skills and knowledge of other cultures are an essential social skill in our increasingly multilingual and multicultural society around the world and here at home. According to Cialdini (2006), people tend to like and are influenced by others who are similar to themselves, which means that we are more likely to be drawn to those who speak our language, and to be influenced by ideas and concepts that are expressed in our language. This is especially important in an era of widespread global mobility, as according to the Migration Policy Institute, in 2015, there were 244M migrants worldwide -- $3.3 \%$ of the global population. If communicative competence is the goal, according to Ethnologue: Languages of the World (n.d.), Chinese, Spanish, and English have the largest number of native speakers, and the choice of target language by the learner or potential learner may vary depending on your geographic location and professional field.

Cultural intelligence (CQ) is driven by 4 factors, CQ Drive; CQ Knowledge, CQ Strategy, and CQ Action (Livermore, 2015). In terms of the significance of multilingualism, or foreign language skills, in the development of cultural intelligence, while all four play a role in learning and using a foreign language for social and 
communicative purposes, it is CQ 2, knowledge, that is of critical importance. Knowledge of the language, and the understanding of the culture that is a hallmark of the best foreign language education, are among the most important social skills in any intercultural encounter or any undertaking of a transnational or multicultural team. The significance of foreign language as a social skill intersects also with its role in creativity. A European Commission report (2009) points to the correlation of multilingualism, a core value of the EU, and creativity, and Kharkhurin (2012) examines the relationship further. Livermore (2016) and Florida (2008) highlight the role of diversity - which could include linguistic diversity - in the creativity of teams.

\section{Global Languages in a Globalized World}

However, the significance of foreign language skills is also demonstrated as the ultimate overarching $21 \mathrm{st}$ century global competency, impacting our personal and professional lives and success, as well as our ability to work together to effectively address complex global issues. As an example of the importance of language(s) in communication, international organizations have official and working languages. For example, the United Nations, with over 190 members, has 6 official languages, and the Secretariat has two working languages, French and English. The European Union has a multitude of official languages and 3 working languages, French, English, and German -- with German the most widely spoken native language in the EU. The Olympics have two official languages, also using the local language of the location of the Games.

Over 1.75 billion people speak English around the world, with over 2B predicted to use it by 2020. Over 220M speak French, and 125M study French, with French predicted to be the most widely spoken native language in Europe by 2025 and the most widely spoken language in the world by 2050 (France Diplomatie, 2017). Bloomberg (2011) has determined that English, Mandarin Chinese, and French are the most useful languages for international business. The UN has 6 official languages, and while the EU has 24 official languages and only 3 official and procedural languages, the Olympics and many international organizations have one or more official languages, indicating the importance of language(s) as a social and communicative skill. While the foreign language sector is estimated at \$40 Billion (USD), with US firms among 3 in the top 5, and estimates of up to $\$ 45$ Billion by 2020 , American students lag behind. While people are studying languages around the world, relatively few Americans are learning another language.

This chronic foreign language deficit, and lack of perceived interest in language leaning, illustrates both a substantial challenge as well as an opportunity to re-visit the benefits of foreign language skills in a contemporary context.

\subsection{Foreign Language Study in a Globalized World}

According to the British Council, nearly 2B people are learning English (British Council, 2013). According to the Organisation internationale de la Francophonie (OIF), 1.25M are studying French. Through the ÉLAN -École et langues nationales en Afrique program, plurilingual French-language education is offered in 12 African nations. While students around the world are studying one or more foreign languages from an early age, in the U.S., foreign language study typically begins later, and many students never study a foreign language.

According to ACTFL enrollment survey (2008), $18.5 \%$ of K-12 public school students were studying a foreign language, and The National K-12 Enrollment Survey (2017) found that $19.66 \%$ were studying another language. According to the MLA, $8.1 \%$ of college and university students are enrolled in a course in a language other than English. This contrasts with current practice in many parts of the world. For example, in Europe, virtually all students study one or more foreign languages from an early grade level, as they do in Asia, Latin America, and the Middle East, where foreign language study typically begins at an early age, and many African nations support bilingual/multilingual education including local languages and an international language.

It is clear that the U.S. lags behind, suffering from a foreign language deficit, which impacts the ability of monolingual English-speaking Americans to effectively navigate the globalized world. 


\subsection{Constructed Languages}

Several languages have been considered global languages at different points in history, but the concept of an artificial, or constructed, language has appealed to many in fostering a sense of equality by favoring no one language or group. According to Ethnologue, Esperanto, with over 2M speakers is the most widely-used constructed, or artificial language. Constructed languages, like Esperanto, intended to facilitate communication across cultures by not favoring any one language or group, have many supporters, but a challenge to their wider use is the significance of language in personal cultural identity.

\subsection{Many Languages One World -- Foreign Language as a Global Competency}

Language is a critical instrument that shapes one's view of the world. Understanding the meaning of the words other people use yields perhaps the most insight into cultural differences. Language both describes and limits what we see. Learning another language offers another view of the world (Adams \& Carfagna, 2006). The Many Languages One World Essay Contest and Global Youth Forum (MLOW) is an example of the significance of multilingualism as a global competency and its role in the development of a global citizenship mindset and skills. Through its use of multilingualism to bring young people together from around the world to discuss complex global issues and to work together to develop action plans to effectively address them.

Launched in 2013 as a collaborative initiative of the United Nations Academic Impact and ELS Educational Services, and inspired by the vision of J. Michael Adams, the late President of Fairleigh Dickinson University, Many Languages One World (MLOW) is intended to highlight the significance of multilingualism in global citizenship and to promote the continued study of the six official languages of the United Nations. Each year, full-time college and university students are invited to submit essays on a pre-determined topic in a learned second language that is also one of the six official languages of the UN. Essay and presentation topics have included the UN Academic Impact Principles and the Sustainable Development Goals (SDGs).

Finalists are interviewed via Skype, and winners are selected. The winners travel to the U.S., where they spend several days working in their language groups on campus, preparing their group presentation and interacting with the other language group winners. Each student has the opportunity to present in the General Assembly Hall of the United Nations in the language of their essay, followed by a luncheon in the Delegates' Dining Room. Students then have an opportunity for New York sightseeing before returning home. This creative initiative, which highlights the significance of multilingualism in working together to effectively address complex global issues, is inspirational in the camaraderie that develops among the diverse group of winners, who have continued to remain in touch afterward through social media and local mini reunions.

\subsection{ELAN-Afrique -- A Francophone Bilingual Education Initiative}

ÉLAN-Afrique (École et langues nationales en Afrique, n.d.) is a collaborative initiative of the OIF, France, and -- at this time -- 12 African nations to develop bilingual education programs, building on initial instruction in the mother tongue in order to foster better student learning outcomes.

\section{Current Trends - Building on the Past, Building for the Future}

2017 has been a watershed year in the public conversation on foreign languages and foreign language education in the U.S., with the release of three major reports in the first half of the year -- America's Languages: Investing in Language Education for the 21st Century; Not Lost in Translation: The Growing Importance of Foreign Language Skills in the U.S. Job Market; and The National K-12 Foreign Language Enrollment Survey. While these reports highlight the need to invest in foreign language education, the importance of foreign language skills as part of global talent in the global marketplace, and the relative lack of progress in increasing interest and enrollment in foreign languages in the U.S. over the past decade, this current momentum is grounded in and framed by earlier research and reports. 
America's Languages: Investing in Language Education for the 21st Century (2017), is a report developed by the American Academy of Arts and Sciences Commission on Language Learning, at the request of a bipartisan group from the U.S. Congress. As the first such report since Strength through Wisdom (Perkins, 1980), it is expected that this report will drive the current conversation on foreign languages and foreign language education in the U.S. for the foreseeable future.

The key findings of the report highlight the critical need for foreign languages as a 21st century skill, the need for foreign language skills in an increasingly multilingual society, the cognitive benefits of foreign languages, the fact that the United States lags behind in foreign language education, the shortage of qualified foreign language teachers, the significance of technology in foreign language learning, and the status of Native American languages.

Key recommendations include increasing the number of foreign language teachers in order to provide access to foreign language education, developing public-private partnerships to support foreign language instruction, supporting heritage language education, supporting Native American languages, and promoting immersion education and study abroad.

Key findings of Not Lost in Translation: The Growing Importance of Foreign Language Skills in the U.S. Job Market (2017) include the increasing demand for bilingual workers, especially in particular fields and geographic regions, and conclusions highlight the need to improve foreign language education, to connect U.S. foreign language speakers with the job market, and importance of the Seal of Biliteracy.

The National K-12 Foreign Language Enrollment Survey found that approximately one in five (19.66\%) $\mathrm{K}-12$ public school students are studying another language, a slight increase over the previous ACTFL enrollment survey, which had placed enrollment at $18.5 \%$, and highlighted the importance of immersion programs.

Earlier reports, which have framed the current conversation, include Foreign Languages and Higher Education: New Structures for a Changed World (2007), from the Modern Language Association, highlighted the importance of translingual and transcultural competence as the goals of foreign language education, the need for multiple pathways to the major, and the importance of K-16 collaborative partnerships. Languages for All? (2014), the final report based on the 2013 conference, highlighted the importance of access to foreign language education.

\section{Challenges -- Awareness, Motivation, Access, Curriculum, and the Need for Advocacy}

In terms of foreign language advocacy, the first challenge is to increase awareness of the importance of foreign language skills and the personal and professional benefits of foreign languages and knowledge of other cultures. Learning another language requires time and effort, so the case for foreign language learning must be made in a compelling and convincing manner. This is a difficult task because, among English-speakers, in the U.S., and to a similar extent, throughout the English-speaking world, there is reluctance to learn another language, based in part at least, on the assumption that, as English is the global lingua franca, there is little need. This assumption, however, is only partially true. While English is the third most widely spoken mother tongue and the most studied second language in the world, $75 \%$ of the world's population does not speak English (British Council, 2013).

As an awareness of the importance and benefits of foreign language would tend to motivate learners to choose to study a foreign language, it is important to develop awareness among prospective learners and their families and communities to create motivation. A concerted effort or campaign to increase awareness among learners of all ages and among parents of young children is needed. An example of this would be the launch of the ACTFL Lead with Languages campaign following the release of America's Languages and the work of many professional and stakeholder groups. 
Foreign language skills as the ultimate 21st century global competency: Empowerment in a globalized world

The second challenge -- creating and sustaining motivation -- is closely related to the first. Motivation can be considered as extrinsic, or based on outside forces and rewards, or intrinsic, or coming from within, and intrinsic motivation has been associated with the best foreign language learning outcomes. Foreign language advocacy plays an important role in effectively addressing both these challenges. Often serving on the front line of language learning and advocacy initiatives, these advocates can, and should, serve as both content experts and sources of motivation when learner motivation may begin to decline. However, motivation needs to be sustained, even though those periods when progress in learning a language can seem to be slow, or to reach a plateau. This is the time when foreign language advocates inside and outside the classroom need to work together in partnership to sustain motivation so that learners stay the course and can reach advanced levels, proficiency, and fluency. Special attention must also be given to local language communities and to programs for heritage language speakers, as heritage language speakers often reflect the local community and may be able to achieve the strongest learning outcomes. This is a time when stakeholder partnerships matter.

At this point, when students are already in the classroom, stakeholder partnerships can make all the difference by creating opportunities for experiential learning and by supporting teachers, and by funding materials, events, and technology in the classroom in collaboration with the classroom teacher. Illustrating the practical applications of foreign language skills can reinforce the importance of acquiring them.

In terms of methodology, a multimodal and immersive foreign language program framed by and grounded in goals of communicative competence and cultural knowledge is generally considered to lead to the most positive learning outcomes. Access is an important issue, as not all schools offer languages in the elementary and middle grades, and not all schools offer a variety of languages or a sequence of levels likely to lead to proficiency. High school graduation and college foreign language requirements are lower than in many parts of the world. According to Pew Research (2015), while most European students are required to study another language, there is no national mandate for foreign language study in the U.S., and the states vary in their requirements, with 16 states having no foreign language requirement for high school graduation (National K-12 Foreign Language Enrollment Survey, 2017). Furthermore, the decline in foreign language study in recent decades has led to a shortage of foreign language teachers and language services professionals, even as interest in foreign languages may be increasing.

In terms of curriculum, interdisciplinary and pre-professional programs are essential in building the foreign language, technical, and business/disciplinary skills needed to maximize the benefit of foreign language skills in the workplace. Increasing awareness, developing and sustaining motivation, broadening access to foreign languages, and developing the programs and curriculum needed to build the skills needed are all critical areas.

In summary, challenges include awareness, motivation, the shortage of qualified foreign language teachers, a lack of foreign language requirements at the K-12 and postsecondary levels, and interdisciplinary and pre-professional programs, especially at the postsecondary level. In addition, there is a widespread attitude among English-speakers that English is the global language and that there is little need to learn additional languages. In light of the reports and research, advocacy efforts, and the public conversation on foreign languages and foreign language skills in the U.S. over several decades, it is remarkable that the number of Americans able to converse in a learned foreign language or enrolled in foreign language study remains relatively unchanged, and relatively small as compared to much of the world, with U.S. K-12 foreign language enrollment only increasing from the $18.5 \%$ in the ACTFL enrollment survey to $19.66 \%$ in the American Councils on International Education National K-12 Foreign Language Enrollment Survey (2017). In addition, college and university enrollment in a language other than English has dropped from $8.6 \%$ to $8.1 \%$ according to the MLA enrollment survey.

\section{Future Directions - Pre-Professional Curriculum, Interdisciplinarity, and Advocacy}

The report of the Commission on Language Learning, America's Languages (2017), the campaign, Lead 
with Languages, launched by the ACTFL immediately following the release of the report, and the New American Economy report, Not Lost in Translation: The Growing Importance of Foreign Language Skills in the U.S. Job Market (2017), and The National K-12 Foreign Language Enrollment Survey (2017) frame the academic and public conversation moving forward.

Immersion programs, pre-professional programs, and career pathways are needed to sustain motivation and to develop proficiency and fluency. However, core values of intercultural understanding and global citizenship drive the development of higher level skills. Authenticity of materials is often discussed, but authenticity of beliefs and attitudes (Gardner, 2010) on the part of the teacher and the learner are essential. In addition, a campaign for foreign languages is needed in order to effect a paradigm shift in the attitude toward foreign language learning in the U.S., and this campaign needs to build on theory and best practice as articulated by Kotter (2008) (change management), Kotler (2015) (social marketing), and Cialdini (2006) (influence and persuasion).

Pre-professional programs and career pathways for foreign language students should build on the concepts of an integrative approach and multiple pathways to the major, as articulated in the MLA report Foreign Languages and Higher Education (2007), and successful examples include the CIBERs and the professional master's degree program in French at the University of Wisconsin. Languages for Specific Purposes, Business Language Studies, and the CLAC (Cultures and Languages across the Curriculum) Consortium offer a broader pathway to global competence through language skills and cultural knowledge. Immersion programs enhance communicative competence, building on the concept of translingual and transcultural competence, as articulated in the MLA report. Well-known examples include New York City's révolution bilingue, the New Orleans and Louisiana immersion programs, the Middlebury College Language Schools, and the Concordia University Language Villages. The core values of global citizenship and global competence are primary drivers of learning and achievement, with Many Languages One World and ELAN as well-known examples.

\section{Conclusions - Empowerment through Foreign Language Skills}

Adams and Carfagna (2006) wrote that "language is a critical instrument that shapes one's view of the world. Understanding the meaning of the words other people use yields perhaps the most insight into cultural differences. Language both describes and limits what we see. Learning another language offers another view of the world." Yet there is a persistent lack of foreign language skills in the U.S., demonstrated in reports and research, with the current conversation beginning with the report of the Presidential Commission, Strength through Wisdom (1979), and Senator Paul Simon's monograph, The Tongue-Tied American: Confronting the Foreign Language Crisis (1980), followed by many more, including Securing America's Future: Global Education for a Global Age (2003), Education for Global Leadership: The Importance of International Studies and Foreign Language Education for U.S. Economic and National Security (2006), International Education and Foreign Languages: Keys to Security America's Future (2007), a U.S. Senate Hearing, A National Security Crisis: Foreign Language Capabilities in the Federal Government (2012), and most recently, the three 2017 reports discussed throughout.

Multilingualism and foreign language skills are important for all of us. While it is especially important for those with English as a mother tongue to remember that only $25 \%$ of the world's population speaks English, and that English may -- or may not -- always be the global lingua franca, it is also important for global citizens around the world to remember the importance of languages and of multilingualism as we attempt to effectively address complex global issues. The importance of many languages, reflecting many perspectives and world views, cannot be overstated, and plurilingualism, a knowledge of both globally and locally important languages, offers a path forward.

Knowledge is power, and foreign language skills and cultural knowledge empower us personally, professionally, and as global citizens. However, the persistent U.S. foreign language deficit, characterized by the 
Foreign language skills as the ultimate 21st century global competency: Empowerment in a globalized world

decline in foreign language majors over a generation, has resulted in a shortage of qualified teachers, decreasing opportunity for foreign language study, just as the realities of an interconnected globalized world are awakening renewed interest in foreign language study in the U.S. The foreign language deficit has created a shortage of translators and interpreters, especially toward English, and a result is that many Americans -- who generally cannot understand what others are saying directly, without a translation -- are increasingly cut off from other views and more isolated in an increasing interconnected world. If awareness, motivation, and skills are among the goals, factors to consider include advocacy, methodology, technology, and curriculum. Advocacy is primarily concerned with increasing awareness of the importance of and benefits of foreign language skills and multilingualism, while the development of foreign language skills depends also on sustainable motivation and community and family support, as well as methodologies -- which include the effective integration of technology in the classroom. Interdisciplinary and pre-professional curriculum, including language, experiential learning, internships, and the development of career pathways are essential in sustaining motivation and developing the needed skills. The centrality of the communicative function and communicative competence cannot be overstated, and builds on the concept of translingual and transcultural competence as articulated in the MLA report, Foreign Languages and Higher Education.

Knowledge is power, and foreign language skills and cultural knowledge empower us personally, professionally, and as global citizens. Foreign language skills and knowledge of other cultures are an essential 21 st century social skill for individuals in their personal lives, as professionals in a globalized marketplace, and as global citizens in a globalized world.

\section{References}

Adams, J. M., \& Carfagna, A. (2006). Coming of age in a globalized world: The next generation. Westport, CT: Kumarian.

Ambient Insight. (2013). The 2013-2018 worldwide digital English language learning market. Retrieved from http://www.ambientinsight.com/Resources/Documents/AmbientInsight-2013-2018-Worldwide-DigitalEnglish-Language-Learning-Market-Executive-Overview.pdf

American Councils on International Education. (2017). The national K-12 foreign language enrollment survey. Retrieved from https://www.americancouncils.org/sites/default/files/FLE-report-June17.pdf

Bloomberg Rankings. (2011). The languages of business. Retrieved from http://www.aatfri.com/pdf\%20files/Bloomberg\%20Rankings_Business\%20languages.pdf

British Council. (2013). The English effect. Retrieved from https://www.britishcouncil.org/sites/default/files/english-effect-report-v2.pdf

British Council. (2014). Languages for the future. Retrieved from https://www.britishcouncil.org/sites/default/files/languages-for-the-future-report-v3.pdf

Bureau of Labor Statistics (2007). The occupational outlook handbook: Interpreters and translators. Retrieved from https://www.bls.gov/ooh/media-and-communication/interpreters-and-translators.htm

Bureau of Labor Statistics. Onet Online. (2017) Summary report for: 25-2031.00 - Secondary school teachers, except special and career/technical education. Retrieved from

https://www.onetonline.org/link/summary/25-2031.00

Bureau of Labor Statistics. Onet Online. (2017). Summary report for: 25-1124.00 - Foreign language and literature teachers, postsecondary. Retrieved from https://www.onetonline.org/link/summary/25-1124.00

Cialdini, R. (2006). Influence: The psychology of persuasion. Boston: Harvard Business.

Commission on Language Learning. (2017). America's languages: Investing in language education for the $21 \mathrm{st}$ century. Retrieved from https://www.amacad.org/content/Research/researchproject.aspx?d=21896

Commonsense Advisory. (2016). Top 100 Language service providers: 2016. Retrieved from http://www.commonsenseadvisory.com/Marketing/2016-largest-LSPs.aspx?utm_source=MLIP+-+Top+ 100+LSPs\&utm_campaign=LSPs\&utm_medium=email

ELAN: École et langues nationales en Afrique. (n.d.). Retrieved from http://www.elan-afrique.org/ 
Stein-Smith, K.

Ethnologue: Languages of the World. (n.d.). Summary by language size. Retrieved from https://www.ethnologue.com/statistics/size

European Commission. (2009). Study on the contribution of multilingualism to creativity. Retrieved from http://eacea.ec.europa.eu/llp/studies/documents/study_on_the_contribution_of_multilingualism_to_crea tivity/compendium_part_1_en.pdf

European Commission. (2012). Europeans and their languages. Retrieved from http://ec.europa.eu/commfrontoffice/publicopinion/archives/ebs/ebs_386_en.pdf

Florida, R. (2008). Who's your city? How the creative economy is making where to live the most important decision of your life. New York: Basic.

France Diplomatie. (2017). The Status of French in the world. Retrieved from http://www.diplomatie.gouv.fr/en/french-foreign-policy/francophony-and-the-french-language/the-statu s-of-french-in-the-world/

Gala-Global. (2017). Translation and localization industry facts and data. Retrieved from https://www.gala-global.org/industry/industry-facts-and-data

Gardner, R. (2010). Motivation and second language acquisition: The Socio-educational model (rev. ed). New York: Peter Lang.

Goldstein, S. (2015). S\&P 500 companies generate barely over half their revenue at home. Retrieved from http://www.marketwatch.com/story/sp-500-companies-generate-barely-over-half-their-revenue-at-home -2015-08-19

Grosjean, F. (2010). Bilingual: Life and reality. Boston: Harvard University Press. https://doi.org/10.4159/9780674056459

Heitner, K. L., \& Miller, L. (2011). The great divide: Worker and employer perspectives of current and future workforce demands. Retrieved from https://research.phoenix.edu/sites/default/files/publication-files/great-divide_0_0.pdf

Hosie, R. (2017). Paris tourist numbers drop due to fears over further terror attacks. Retrieved from http://www.independent.co.uk/travel/paris-tourist-numbers-drop-franch-terror-attacks-further-charlie-he bdo-bataclan-shooting-isis-a7592836.html

ICEF Monitor. (2016). UK’s English language teaching sector worth $£ 1.2$ billion. Retrieved from http://monitor.icef.com/2016/02/uks-english-language-teaching-sector-worth-1-2-billion/

ICEF Monitor. (Nov., 2015). New OECD report summarizes global mobility trends. Retrieved from http://monitor.icef.com/2015/11/new-oecd-report-summarises-global-mobility-trends/

Institute of International Education. (2017). Open doors 2016. Retrieved from http://www.iie.org/Research-and-Publications/Open-Doors/

International Publishing Association. (2014). Annual report 2013-2014. Retrieved from https://www.internationalpublishers.org/images/reports/2014/IPA-annual-report-2014.pdf

International Trade Administration. (2016). New study: How important is FDI to the U.S. economy? Retrieved from https://blog.trade.gov/2016/02/24/new-study-how-important-is-fdi-to-the-u-s-economy/

JNCL-NCLIS Update. (2015). October 2015 update. Retrieved from https://languagepolicy.org/wp-content/uploads/2016/08/October-2015-Update.pdf

Johnson: What is a foreign language worth? (Mar 2014). Economist. Retrieved from http://www.economist.com/blogs/prospero/2014/03/language-study

Kharkhurin, A. V. (2012). Multilingualism and creativity. Bristol, UK: Multilingual Matters.

Kinzler, K. (2016). The superior social skills of bilinguals. Retrieved from https://www.nytimes.com/2016/03/13/opinion/sunday/the-superior-social-skills-of-bilinguals.html?_r=0

Kotler, P., \& Lee, N. R. (2015). Social marketing: Changing behaviors for good $\left(5^{\text {th }}\right.$ ed). Thousand Oaks, CA: SAGE.

Kotter, J. (2008). A sense of urgency. Boston: Harvard Business Press.

Kurtz, A. (2013). The hottest job skill is... Retrieved from http://money.cnn.com/2013/10/30/news/economy/job-skills-foreign-language/

LingoKing. (2016). The international language services market. Retrieved from 
Foreign language skills as the ultimate 21st century global competency: Empowerment in a globalized world https://www.lingoking.com/en/about-us/press/the-international-language-services-market/

Livermore, D. (2016). Driven by difference: How great companies fuel innovation through diversity. New York: AMACOM.

Livermore, D., \& Ang, S. (2015). Leading with cultural tntelligence: The Real secret to success (2nd ed.). New York: AMACOM.

Many Languages One World. (n.d.). Retrieved from https://www.manylanguagesoneworld.org/

Marian, V., \& Shook, A. (2012). The cognitive benefits of being bilingual. Cerebrum. Retrieved from https://www.ncbi.nlm.nih.gov/pmc/articles/PMC3583091/

McComb, C. (2001). About one in four Americans can hold a conversation in a second language. Retrieved from http://www.gallup.com/poll/1825/about-one-four-americans-can-hold-conversation-second-language.as px

McLuhan, M., \& Fiore, Q. (1967). The Medium is the massage. Penguin.

Migration Policy Institute. (2017). International migration statistics. Retrieved from http://www.migrationpolicy.org/programs/data-hub/international-migration-statistics

Modern Language Association. (2007). Foreign languages and higher education: New structures for a changed world. Retrieved from https://www.mla.org/Resources/Research/Surveys-Reports-and-Other-ModernDocuments/Teaching-Enr ollments-and-Programs/Foreign-Languages-and-Higher-Education-New-Structures-for-a-Changed-Worl $\underline{\mathrm{d}}$

Modern Language Association. (2015). Enrollments in languages other than English in United States institutions of higher education. Retrieved from

https://www.mla.org/Resources/Research/Surveys-Reports-and-Other-Documents/Teaching-Enrollment s-and-Programs/Enrollments-in-Languages-Other-Than-English-in-United-States-Institutions-of-Higher -EducationWeb

National Association of Colleges and Employers. (2016). Philosophy projected as top-paid class of 2016 humanities major. Retrieved from

http://www.naceweb.org/job-market/compensation/philosophy-projected-as-top-paid-class-of-2016-hu manities-major/

Neeley, T., \& Kaplan, R. S. (Sept., 2014). What's your language strategy? Harvard Business Review.

New American Economy. (2017). Not lost in translation: The growing importance of foreign language skills in the U.S. job market. Retrieved from

http://www.newamericaneconomy.org/research/not-lost-in-translation-the-growing-importance-of-forei gn-language-skills-in-the-u-s-job-market/

Organisation internationale de la Francophonie. (2014). La Langue française dans le monde. Retrieved from https://www.francophonie.org/Langue-Francaise-2014/projet/Rapport-OIF-2014.pdf

Owler. (2017). Simon and Schuster Pimsleur company profile. Retrieved from https://www.owler.com/iaApp/716154/simon---schuster--pimsleur-company-profile

Perkins, J. (1980). Strength through wisdom: A critique of U.S. capability. Modern Language Journal, 64(1), 9-57. https://doi.org/10.1111/j.1540-4781.1980.tb05167.x

Pew Research. (2016). Wikipedia at 15: Millions of readers in scores of languages. Retrieved from http://www.pewresearch.org/fact-tank/2016/01/14/wikipedia-at-15/

Reagan, T. (2004). Don't know much about the French I took: A Contemporary case for second language study in the liberal arts. Arts \& Humanities in Higher Education, 3(2), 229-239.

https://doi.org/10.1177/1474022204042688

Ryan, C. (2013). Language use in the United States: 2011. Retrieved from https://www.census.gov/prod/2013pubs/acs-22.pdf

Statista. (2017). Most common languages used on the internet as of June 2016, by share of internet users. Retrieved from https://www.statista.com/statistics/262946/share-of-the-most-common-languages-on-the-internet/

Togo: L'Introduction des langues maternelles à l'école à travers l'initiative ELAN. (Oct., 2016). Retrieved from 
Stein-Smith, K.

http://news.icilome.com/?idnews=828975\&t=l-introduction-des-langues-maternelles-a-1-ecole-a-travers -1-initiative-elan

U.S. Census. (2016). Top trading partners. Retrieved from https://www.census.gov/foreign-trade/statistics/highlights/top/top1612yr.html

UN World Tourism Organization. (n.d.). Why tourism? Retrieved from http://www2.unwto.org/content/why-tourism

United Nations. Sustainable Development Goals. (Sept., 2015). Retrieved from http://www.un.org/sustainabledevelopment/sustainable-development-goals/

World Trade Organization. (2016). Tourism sector highlighted as important contributor to trade and development. Retrieved from https://www.wto.org/english/news_e/news16_e/bus_13jul16_e.htm 